\title{
大学生の食生活の意識について
}

\author{
飯田文子* ·高橋智子* ·川野亜紀 $*$ 渡辺敦子** · 大越ひろ*・三輪里子*** \\ (*日本女子大学. $* *$ 茨城キリス卜教大学. $* * *$ 十文字学園女子短期大学 $)$
}

\section{College Students' Awareness and Habits on Eating}

Fumiko Iida*, Tomoko Takahashi*, Aki Kawano*, Atsuko Watanabe**, Hiro Ogoshi*, Satoko Miwa***

*Japan Wamen's University, 2-8-1, Mejirodai, Bunkyou-ku, Tokyo, 112-8681

**Ibaraki Christian University, 6-11-1, Omika-cho, Hitachi-shi, Ibaraki, 319-1295

***Jumonji Gakuen College, 2-1-28, Sugasawa, Niiza-shi, Saitama, 352-8510

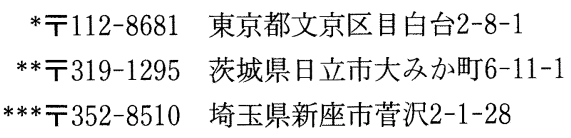

A fact-finding survey was followed by an awareness survey, with the same individuals serving as the survey subjects, for determining their food preference, analyzing the various factors that comprised their eating habits, and shedding light on their general attitude toward eating.

1. A difference between genders was revealed in food preference. Male students favored Western and Chinese foods with a focus on meat, whereas female students preferred snack-type Western foods.

2. The factors which scored the highest points (specifically, those that earned 1.0 or more on the eigenvalue) indicated that both the male and female students perceived their own eating habits as "eating irregularly and choosing foods according to personal preference."

3. Male students ate out for socializing and for spiritual contentment although they were not satisfied with the contents of such meals. Female students, in contrast, were discontent with the taste of the food when eating out, but did so because it was convenient and saved time.

4. The study on college students' awareness of meals disclosed that they gained little satisfaction from their meals, tended to eat at different hours compared with other family members, and had no negative feelings about eating alone.

\section{1. 緒言}

現代の大学生は学業のほかサークル活動やアルバイト などを行っており, 一日の大半を家庭外で過ごし, 半ば 家庭より独立した存在にあるといえるので, 彼らの食生
活の特徴を捉える試みが必要といえる.このような視点 から, 著者らは大学生の食生活の現状を把握するために, 大学生の食に着目し，「いつ」,「どこで」,「だれと」,

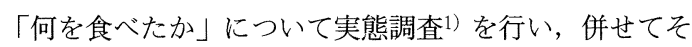


の食行動を動機づける意識に関しての調査を試みた．前 報1)では, 男女学生の生活時間調査と食事記録から大学 生の食生活の実態について報告した。大学生の一日の生 活の中での食事時間の位置付けは曖昧でけじめがなく, 喫食状態は24時間にわたり分散しており，したがって， 食事内容は単品ものが多く, 食事として整った内容のも のは少ないという結果を得た.

大学生の食生活に関する研究としては，村田 ${ }^{2)}$ や相川 ら3) の女子大生の栄養摂取と生活時間に関する研究, 田 辺ら ${ }^{4)}$ の大学生の生活価值観と食生活に関する研究など がある.これらの研究は栄養摂取や生活価值観などの研 究であり，現代の若者の食に関する意識に対する検討は ほとんどなされていない.食に関する意識調査としては, 1990年代前半に，染谷 $\left.{ }^{5}, 6\right)$ の女子短大生の食生活の実 態調査, 平井ら ${ }^{7)}$ の男子学生の食生活と健康に関する意 識調査の研究がある.しかし，大学生の意識は年々変化 しており, 生活時間においても著しい変化が認められて いる1).

本研究では彼らの食墸好や食事観，食生活に関する意 識などについて調査を行い，同時に行った前報1)の結果 と併せ考察することで, 現代の大学生の食生活実態を明 らかにすることを試みたので，結果を報告する．

\section{2. 方 法}

\section{（1）調査時期および対象}

1997年の 6 月〜 10月に行った実態調査1) とあわせて， 同対象，すなわち東京都内の 24 大学に在学する508名と した.

\section{（2）調查内容および解析方法}

調査内容は, 男女学生の食嗜好, 食生活や食事に関す る関心度などについての意識調査とした。食嗼好として, 予備調査で頻度の高かった47品目の料理を調査項目（表 1）とした. 表 1 に示した 47 品目から「好きな料理」扔 よび「よく食べる料理」を各 5 個ずつ抽出してもらい, 男女別に林の数量化理論第 3 類を適用し，その構造を解 析した．食生活への意識として，日常の食事に対する10 項目（表 3 参照）および外食に対する15項目（表 4 参照） をそれぞれ質問項目とし，そう思うを 1 点，どちらでも ないを 2 点，そう思わないを 3 点として，男女別に因子 分析（主因子法・バリマックス回転）を用い，検討を行 った，さらに，食生活への関心度については，「自分の 食生活に興味があるか」，「料理に関する番組や雑誌など に興味があるか」,「話題となっている店や食べ物に興味 があるか」の 3 項目（図 3 参照）について質問した。 た，食事に関する関心度については，「現在の食事をど のように思うか」，「一人で食事をしてもおいしいと思う 功，「食事に時間をかけたいと思うか」，「家族と食事の 時間のずれを気にするか」，「食卓が家族の結びつきを強 めていると思うか」，「家庭での食事で最も重視するもの はぞれか」の 6 項目（図 4 参照）を質問した。いずれの 質問項目についても，男女別抢よび住まい方別にクロス 集計を行った、いずれの解析も統計ソフトはSPSS, 統 計解析 For win を用いた。

\section{3. 結果および考察}

\section{（1）対象者の属性}

アンケート調査に抢ける有効回答者数は, 男子学生 95 名，女子学生109名の合計204名（回収率40\%）であった.

表 1 料理名

\begin{tabular}{|c|c|c|}
\hline $\begin{array}{l}\text { 1. カレーライス } \\
\text { 2. チャーハン・ピラフ } \\
\text { 3. オムレツ・オムライス } \\
\text { 4. グラタン・ドリア } \\
\text { 5. リゾット } \\
\text { 6. スパゲティ } \\
\text { 7. うどん·そば類 } \\
\text { 8. ラーメン } \\
\text { 9. やきそば } \\
\text { 10. ピザ } \\
\text { 11. 寿司 } \\
\text { 12. 井もの } \\
\text { 13. お好み焼き·たこ焼き } \\
\text { 14. おにぎり } \\
\text { 15. 肉まん } \\
\text { 16. ハンバーガー }\end{array}$ & $\begin{array}{l}\text { 17. サンドイッチ } \\
\text { 18. 菓子パン·調理パン } \\
\text { 19. お茶漬け·雑炊 } \\
\text { 20. シチュー } \\
\text { 21. マーボー豆腐 } \\
\text { 22. 酢豚 } \\
\text { 23. ステーキ・ハンバーグ } \\
\text { 24. 焼き肉 } \\
\text { 25. 焼き鳥 } \\
\text { 26. 鍋物 } \\
\text { 27. 肉じゃが } \\
\text { 28. フライドチキン } \\
\text { 29. シュウマイ } \\
\text { 30. 餃子 } \\
\text { 31. 春巻 } \\
\text { 32. コロッケ }\end{array}$ & $\begin{array}{l}\text { 33. 天ぷら } \\
\text { 34. 刺身 } \\
\text { 35. 焼き魚 } \\
\text { 36. 煮魚 } \\
\text { 37. フライ·カツ } \\
\text { 38. 野菜炒め } \\
\text { 39. サラダ類 } \\
\text { 40. お浸し } \\
\text { 41. 野菜煮物 } \\
\text { 42. 酢の物·和え物 } \\
\text { 43. きんぴらごぼう } \\
\text { 44. 冷やっこ・湯豆腐 } \\
\text { 45. 茶碗蒸し } \\
\text { 46. みそ汁 } \\
\text { 47. スープ類 }\end{array}$ \\
\hline
\end{tabular}
回収率が低い要因として，先に報告 した実態調査1)を同時に行ったた め，回答者の負担が大きかったこと が挙げられよう。回答者の出身地は

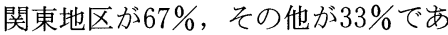
った．住まい方から分類すると，男 子学生は，家族と同居 $60 \%$, 一人暮 らし $40 \%$ の割合に対して，女子学生 は家族と同居 $61 \%$ ，一人暮らし $39 \%$ とほぼ同比率であった，また学生生 活において，学業以外に生活時間に 影響を与える要因であるサークル活 動あるいはアルバイトをしているも のは，全体の90\%を占めていた。 


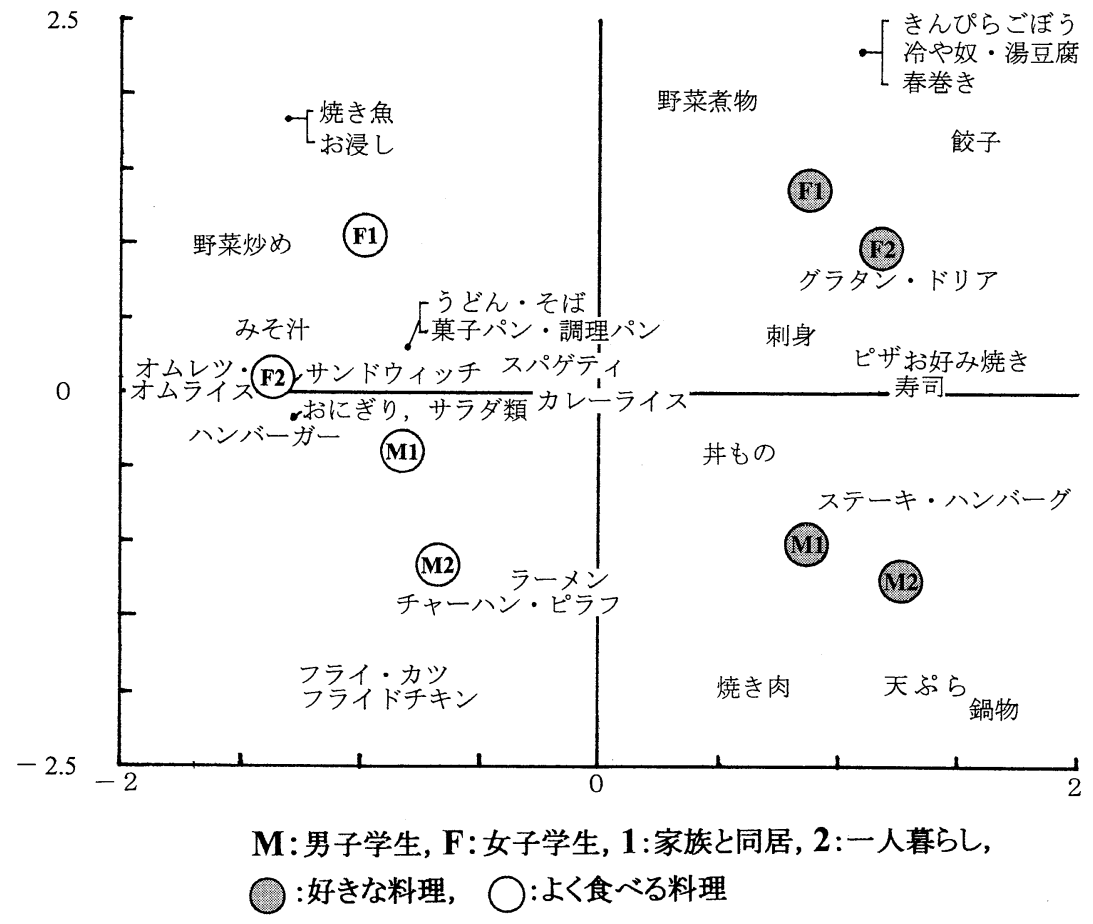

図 1 男女学生の好きな料理とよく食べる料理の関係（料理名の二次元散布図）

\section{（2）大学生の食嗜好}

\section{1)「好きな料理」および「よく食べる料理」}

前報1）の大学生の食事時間と食生活の実態の調査か ら，彼らの食生活の特徵をまとめると，(1)時間がまちま ち, (2)食事内容は一品ものが多い, (3)外食が高頻度, と の結果が得られている，そこで，このような食事をとっ ている学生達の嗜好性の特徵をより詳細に知るため，同 時に行った食嗜好に関する調査である「好きな料理」お よび「よく食べる料理」について検討を行った.

予備調査でそれぞれ頻度の高かった料理47品目（表 1) から，大学生の「好きな料理」および「よく食べる料理」 を 5 品目ずつ選択させ, 数量化理論第 3 類を用い, 図 1 に示すような 2 次元散布図を得た．原点附近にプロット された「カレーライス」「スパゲティ」は男女共に好き でよく食べる料理といえる，X軸，Y軸ともにプラスの 第 1 象限は女子学生の「好きな料理」, X軸がプラスで Y 軸がマイナスの第 2 象限は男子学生の「好きな料理」, $\mathrm{X}$ 軸, $\mathrm{Y}$ 軸共にマイナスの第 3 象限は男子学生の「よく 食べる料理」, $\mathrm{X}$ 軸がプラスで $\mathrm{Y}$ 軸がマイナスの第 4 象 限は女子学生の「よく食べる料理」がプロットされてい る.
これらの結果から, 男子学生の「好きな料理」はステー キ，焼肉，天ぷらなどに代表されるたんぱく質の豊富な 料理を好む傾向が伺われた，また，男子学生の「よく食 ベる料理」は，ラーメン，チャーハン，井物などのいず れも安価でボリュームのある一品料理であった，一方， 女子学生の「好きな料理」はグラタン, ピザ, 寿司,

「よく食べる料理」は菓子パン， サラダ，みそ汁，おに ぎりなどで，一品料理のほか，汁物や副菜も含まれてい た。

\section{2 ）「よく食べる料理」の栄養的検討}

そこで，「よく食べる料理」について，男女学生別に 上位 6 位までをまとめ, エネルギーと PFC 比を算出し あわせて示したものが表 2 である.

男子学生は一品ものを好み，その平均エネルギーは $381 \pm 123 \mathrm{kcal}$, 平均脂質量 $10.3 \mathrm{~g}$ であり, 脂質エネルギー 比率をみると $24.2 \%$ になった。こと脂質エネルギー比 率が高い調理パン（カレーパン） 52\%とチャーハン $33 \%$ を一品料理として摂る場合には，脂質エネルギ一比率を 下げるような食事の工夫を認識できるような食教育の必 要性があるといえよう。

一方, 女子学生のよく食べる料理には一品ものに加え, 
表 2 よく食べる料理一上位 6 品目のエネルギーと PFC 比 (1) 男子学生

\begin{tabular}{c|l|c|c|l}
\hline 順位 & \multicolumn{1}{|c|}{ 料理名 } & $\begin{array}{c}\text { エネルギー } \\
(\mathrm{kcal})\end{array}$ & $\begin{array}{c}\text { PFC 比 } \\
(\%)\end{array}$ & \multicolumn{1}{|c}{ 備考 } \\
\hline 1 & ラーメン & 323 & $20: 18: 62$ & \\
\hline 2 & カレーライス & 561 & $14: 20: 64$ & \\
\hline 3 & 井もの & 472 & $17: 22: 61$ & 親子井 \\
\hline \multirow{2}{*}{4} & 菓子パン & 163 & $11: 17: 72$ & 蒸しパン \\
& 調理パン & 303 & $12: 52: 36$ & カレーパン \\
\hline \multirow{2}{*}{5} & チャーハン & 466 & $12: 33: 55$ & カレーピラフ \\
& ピラフ & 417 & $11: 21: 68$ & \\
\hline \multirow{2}{*}{6} & うどん・ & 277 & $12: 10: 78$ & タヌキうどん \\
& そば類 & 446 & $16: 24: 60$ & キツネそば \\
\hline & 平均 & $381 \pm 123$ & & \\
\hline
\end{tabular}

(2) 女子学生

\begin{tabular}{c|l|c|c|l}
\hline 順位 & \multicolumn{1}{|c|}{ 料理名 } & $\begin{array}{c}\text { エネルギー } \\
(\mathrm{kcal})\end{array}$ & $\begin{array}{c}\text { PFC 比 } \\
(\%)\end{array}$ & \multicolumn{1}{c}{ 備考 } \\
\hline 1 & $\begin{array}{l}\text { 菓子パン } \\
\text { 調理パン }\end{array}$ & $\begin{array}{c}163 \\
303\end{array}$ & $\begin{array}{c}11: 17: 72 \\
12: 52: 36\end{array}$ & $\begin{array}{l}\text { 蒸しパン } \\
\text { カレーパン }\end{array}$ \\
\hline 2 & みそ汁 & 54 & $27: 52: 21$ & 豆腐とわかめ \\
\hline 3 & スパゲティ & 624 & $15: 28: 53$ & ミートソース \\
\hline 4 & サラダ類 & 174 & $12: 62: 26$ & ポテトサラダ \\
\hline 4 & おにぎり & 378 & $9: 4: 87$ & \\
\hline 6 & カレーライス & 561 & $14: 20: 64$ & \\
\hline 6 & うどん・ & 277 & $12: 10: 78$ & タヌキうどん \\
& そば類 & 446 & $16: 24: 60$ & キツネそば \\
\hline 6 & サンドイッチ & 439 & $14: 32: 54$ & ミックスサンド \\
\hline 6 & 野菜炒め & 165 & $33: 36: 31$ & 五目炒め \\
\hline & 平均 & $326 \pm 180$ & & \\
\hline
\end{tabular}

みそ汁やサラダ類, 野菜炒めなどの汁物や副菜が含まれ ている.よく食べる料理のエネルギ一の総平均は $326 \pm$ $180 \mathrm{kcal}$ であり, 副菜を含むためばらつきが大きくなっ ているが，主食に当たる一品ものに限定した場合の平均

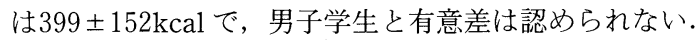
しかし，よく食べる料理には副菜が含まれていることか ら，男子よりは食事のバランスを考慮している傾向が伺 われる。

以上のことと, 前報1) で示した昼食を単品で斉ませて いる実態を併せて考えると, 健康に生活するための食教 育の必要性を強く感じる.すなわち, 一回分あるいは一 日分の食事として栄養的にバランスのとれた食事を契食 するための知恵と知識をどのように習得させることが出
来るのかが，今後の課題といえよう.

\section{（3）大学生の食生活意識}

\section{1）日常の食事に対する意識}

大学生の食事に対する意識について, 表 3 に示すよう な10項目について質問し，その結果を因子分析で男女別 に検討した. 表 3 はバリマックス回転後の因子負荷量を 示したものである.

固有值 0.7 以ををとつの指標とすると, 男子学生の 食事に対する意識は，第 1 因子として「品数が多い」, 「バランスが良い」などの栄養に関する因子, 次いで第 2 因子には「おいしい」，「食べたいものを食べている」 などの嗜好を示唆する因子が挙がってくる．第 3 因子は 「規則正しい」が負の負荷量を示し，因子として不規則 性が挙げられている. 一方, 女子学生ではマイナス因子 が第一に挙がり，第 1 因子として，「バランスが良い」,

「規則正しい」,「品数が多い」などが負の負荷量として 示され，すなわち，日常の食生活への反省の意味をこめ た栄養に関するマイナスの因子が挙げられている. 次い で，第 2 因子には「おいしい」「食べたいものを食べて いる」,「食卓の雲囲気が良い」，「打金をかけている」の 4 因子，すなわち，嗜好性と贅沢性に関する因子が挙が っている.

これらのことから, 男子学生よりも女子学生の方が健 康に留意した食事を望んではいるが，日常の食事を振り 返ってみると，峳しい評価となったものといえよう。一 方, 男女学生ともに嗜好重視と不規則性が共通の意識と して挙げられていた. 殊に女子学生特有のものとして, 食卓の雾井気を大切にしたいという食卓環境への意識が みられた。

\section{2 ）外食に対する意識}

前報の実態調査1) で大学生の外食頻度が高い結果を得 たが，意識調査においても同様の傾向が認められた. 図 2 に示すように, 外食を毎日していると回答したものは, 全学生で約 $47 \%$ である. しかし, 前報1)によると外食は 昼食にほとんど出現しており，このように高い外食率は 大学食堂での食事を外食として位置づけているための影 響といえよう.

大学生の外食に対する意識について, 表 4 に示すよう な15項目について質問し，その結果を因子分析で男女別 に検討した. 表4はバリマックス回転後の因子負荷量を 示したものである. 固有值 1 以上でみると男子は因子 3 まで，女子は因子 5 までである.

外食に対する意識として, 男子学生は「味が濃い」, 「油っこい」を第 1 因子として挙げており，外食の料理 
表 3 日常の食事に対する意識

男子学生一食事評価における各尺度の因子負荷量（バリマックス法）

\begin{tabular}{|c|c|c|c|c|}
\hline \multicolumn{2}{|r|}{ 調査項目 } & \multirow{2}{*}{$\begin{array}{l}\text { Factor } 1 \\
0.76487\end{array}$} & \multirow{2}{*}{$\frac{\text { Factor } 2}{0.06769}$} & \multirow{2}{*}{$\begin{array}{r}\text { Factor } 3 \\
-0.01529\end{array}$} \\
\hline 5 & 品数が多い & & & \\
\hline 4 & バランスがよい & 0.67573 & 0.05839 & -0.37322 \\
\hline 2 & 食べたいものを食べている & -0.06191 & 0.60197 & 0.11567 \\
\hline 1 & 抒いしい & 0.25820 & 0.59316 & -0.09838 \\
\hline 6 & 規則正しい & 0.26456 & -0.00694 & -0.62668 \\
\hline 3 & 過食気味 & -0.08402 & 0.21210 & 0.14976 \\
\hline 7 & 自分で作る & -0.04725 & -0.30308 & -0.07635 \\
\hline 9 & お金をかけている & 0.15224 & 0.08364 & 0.18522 \\
\hline 10 . & 好き嫌いが多い & -0.19489 & 0.12807 & 0.29212 \\
\hline \multirow[t]{3}{*}{8} & 食卓の雲囲気がよい & 0.32822 & 0.39334 & -0.04026 \\
\hline & 固有値 & 1.36031 & 1.03720 & 0.70484 \\
\hline & 累積寄与率（\%） & 13.6 & 24.0 & 31.0 \\
\hline
\end{tabular}

女子学生一食事評価における各尺度の因子負荷量（バリマックス法）

\begin{tabular}{clrr}
\hline & \multicolumn{1}{c}{ 調査項目 } & Factor 1 & Factor 2 \\
\hline 4 & バランスがよい & -0.71590 & 0.05528 \\
6 & 規則正しい & -0.67146 & 0.07460 \\
5 & 品数が多い & -0.55006 & 0.35304 \\
1 & おいしい & -0.29151 & 0.65655 \\
8 & 食卓の需团気がよい & -0.25082 & 0.51370 \\
9 & 打金をかけている & 0.19390 & 0.49624 \\
2 & 食べたいものを食べている & 0.01088 & 0.46999 \\
10 & 好き嫌いが多い & -0.11495 & 0.12616 \\
7 & 自分で作る & -0.04247 & -0.12526 \\
3 & 過食気味 & -0.03761 & 0.15969 \\
\hline & 固有值 & 1.46797 & 1.35247 \\
\hline \hline
\end{tabular}

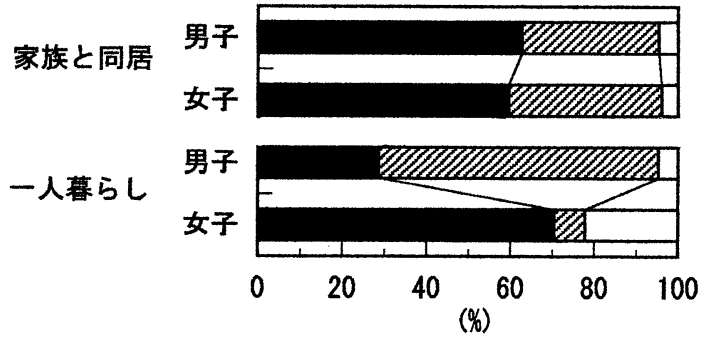

ほとんど毎日 $\square$ 月に2〜3回

囚调に2〜3回

図 2 外食の頻度

はくどいという意識が示されている．第 2 因子には「お いしくてよい」,「野菜がとれる」,「ボリューウムがある」, 「衛生的である」がすべて負の負荷量を示し, 外食は好 ましくないという否定的な意識が認められ，第 2 因子ま
でで寄与率20\%を占めた．次に挙げられる 第 3 因子には，「友人や家族と楽しい時を過 ごせる」,「気分転換になる」などの精神的 やすらぎに関する意識が挙げられた。

一方，女子学生は第 1 因子として，「味が 濃い」,「油っこい」,「ボリュームがある」 など，外食の料理はくどくて，量が多いと 考える因子を挙げていた，第 2 因子には，

「経済的」,「便利」のような利便性に関す る因子と，「野菜がとれる」，「衛生的」，「お いしい」などの, 嗜好性や栄養に関する因 子を挙げていた。一方, 第 3 因子として挙 げられていたものには,「友人や家族と楽し い時が過ごせる」,「気分転換になる」が負 の因子として出現し，男子学生とは全く対 象的な因子として特筆すべきものであろう．第 4 因子は 「添加物が気になる」,「続けると飽きる」,「できれば家 で食べたい」などの外食を否定するような因子，第 5 因 子には「一人では抵抗がある」「特別なこと」が負とし て挙げられ, 外食は特別なことではなく, 日常的なもの とする因子が挙がっていた。

以上のことより, 男子学生は「外食の内容には満足し ていないが, 社交や精神的なやすらぎをもとめ」て外食 し, 女子学生は「味に不満はあるものの, 便利さや手軽 さゆえに外食し, 外食に精神的なやすらぎを求めていな い」など, 男女学生の意識に明確な差が認められた。

(4) 大学生の食事観

\section{1）食生活への関心度}

日常の食事に対する意識にも見られたが，実際に大学 生が自分の食生活をどのように考えているかを知る目的 で, 図 3 に示した食に関する 3 項目の質問を行い, その 結果を示した.

「自分の食生活への興味」に対する質問では, 女子学 生の $52 \sim 68 \%$ が関心が「とてもある」と回答し, 男子学 生, 特に家族と同居している学生では,「あまりない」, 「全くない」の回答が約 $45 \%$ と半数を占めた. 一方, 「とてもある」の回答は住まい方を問わず，男子学生の 約 $20 \%$ 占め, これは女子学生の回答の $\frac{1}{2}$ であり, 男女 の食生活に対する意識の差が伺われた.

この傾向は「料理番組・雑誌への興味」や「話題にな っている店や食べ物への関心度」についてもほぼ同様の 傾向がみられ，いずれの質問に対しても女子学生の関心 度が高かった。 
表 4 外食に対する意識

男子学生一外食評価における各尺度の因子負荷量（バリマックス法）

\begin{tabular}{clrrr} 
& \multicolumn{1}{c}{ 調査項目 } & Factor 1 & Factor 2 & Factor 3 \\
\hline 6 & 油っこい & 0.86854 & -0.04915 & 0.00978 \\
5 & 味が濃い & 0.86847 & 0.04801 & -0.09025 \\
3 & おいしくてよい & -0.02220 & -0.60435 & 0.27063 \\
4 & 野菜がとれる & -0.04040 & -0.52246 & 0.20356 \\
7 & ボリュームがある & 0.22597 & -0.49409 & -0.15912 \\
9 & 衛生的である & -0.28270 & -0.34867 & 0.31794 \\
11 & 気分転換になる & -0.05781 & -0.09208 & 0.59625 \\
10 & 友人や家族と楽しい時を過ごせる & -0.12805 & -0.18534 & 0.58628 \\
8 & 添加物が気になる & 0.21182 & 0.25506 & 0.00822 \\
13 & 特別なことだ & 0.00196 & -0.20167 & 0.26562 \\
2 & 便利である & 0.14817 & 0.07675 & 0.08405 \\
14 & 一人では抵抗がある & 0.00631 & 0.05287 & 0.23425 \\
1 & 経済的である & 0.10343 & 0.12043 & -0.00625 \\
12 & できれ゙゙家で食べたい & 0.06651 & 0.07763 & -0.07085 \\
15 & 続けると飽きる & -0.01476 & 0.10440 & 0.06199 \\
\hline & 固有值 & 1.74364 & 1.19728 & 1.09002 \\
\hline \hline & 累積寄与率（\%) & 11.6 & 19.6 & 26.9 \\
\hline
\end{tabular}

女子学生一外食評価における各尺度の因子負荷量（バリマックス法）

\begin{tabular}{llrrrrr}
\hline & \multicolumn{1}{c}{ 調査項目 } & Factor 1 & Factor 2 & Factor 3 & Factor 4 & \multicolumn{1}{c}{ Factor 5 } \\
\hline 5 & 味が濃い & 0.76313 & 0.02188 & -0.13218 & 0.07116 & -0.03213 \\
6 & 油っい & 0.72567 & 0.00232 & 0.03847 & 0.18242 & -0.23947 \\
7 & ボリュームがある & 0.41767 & 0.33098 & -0.03716 & 0.04562 & -0.11324 \\
1 & 経済的である & 0.13115 & 0.62435 & -0.18302 & 0.02988 & -0.20672 \\
4 & 野菜がとれる & -0.08498 & 0.57418 & -0.20354 & 0.11276 & -0.06613 \\
9 & 衛生的である & -0.15642 & 0.56115 & -0.33503 & 0.14594 & 0.04119 \\
3 & おいしくてよい & 0.16886 & 0.55387 & -0.12406 & -0.34499 & -0.01782 \\
2 & 便利である & 0.29699 & 0.38825 & -0.03406 & 0.07233 & 0.08719 \\
11 & 気分転換になる & -0.01987 & 0.21731 & -0.73072 & -0.03645 & -0.03267 \\
10 & 友人や家族と楽しい時を過ごせる & 0.21542 & 0.13643 & -0.63712 & -0.06560 & -0.21711 \\
8 & 添加物が気になる & 0.30786 & 0.03497 & 0.06049 & 0.63398 & -0.04012 \\
15 & 続けると飽きる & 0.06547 & 0.03244 & -0.01679 & 0.61020 & -0.20697 \\
12 & できれば家で食べたい & 0.28488 & 0.03353 & 0.13154 & 0.43293 & -0.10028 \\
14 & 一人では抵抗がある & 0.11928 & 0.03035 & -0.10919 & 0.16770 & -0.68122 \\
13 & 特別なことだ & 0.24891 & 0.15172 & -0.12843 & 0.02306 & -0.57751 \\
\hline & 固有值 & 1.75224 & 1.69510 & 1.21358 & 1.19557 & 1.02821 \\
\hline \hline & 累積寄与率(\%) & 11.7 & 23.0 & 31.1 & 39.0 & 45.9 \\
\hline
\end{tabular}

\section{2 ) 食事への関心度}

図 4 に，家族と食事に関する 6 項目の質問とその結果 を示した

質問 1 の「現在の食事」への満足度には住まい方によ る差がみられ，「あまり満足でない」と「不満」が男女 学生とも，家族と同居している場合には $15 \sim 25 \%$ と低率 であるが，一人暮らしの学生では $46 〜 70 \%$ を占め, 不満 の割合が高かった。このことは一人暮らしのため, 台所
設備の不備（ミニキッチンが多い）や一人分の調理が面 倒であることもその要因といえよう.

質問 2 の「人で食事をした時においしいか」に対し て, 男女学生ともに「いいえ」が平均 $25 \%$ を占めていた。 しかし,男子学生では住まい方による差が顕著にみられ， 家族と同居の場合には「はい」が $42 \%$ で，「いいえ」の $22 \%$ を回り, 孤食を肯定し，一人暮らしでは，やや 「いいえ」の $25 \%$ に対して「はい」が21\%に留まってい

$172(88)$ 
(1) 自分の食生活に興味がありますか

男子

家族と同居

一人暮らし

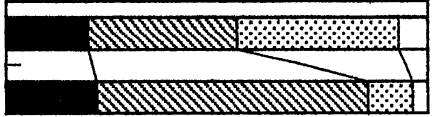

女子

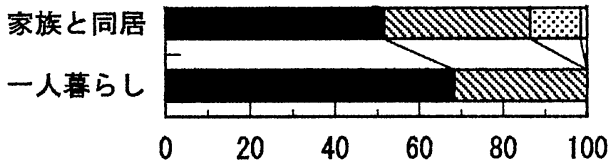

(\%)

正てもある 国 あまりない

四しある $\square$ 全くない

(2) 料理に関する番組や雑誌などに興味がありますか

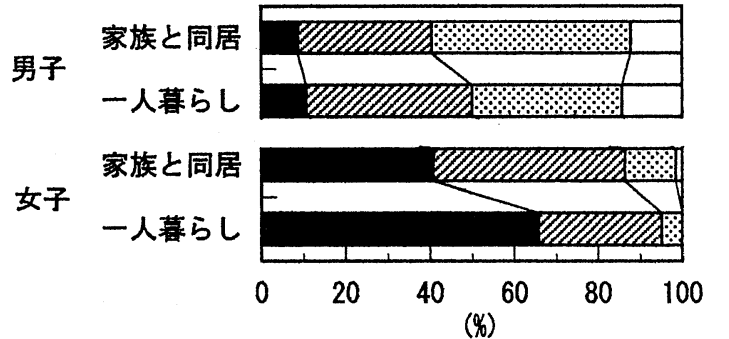

とてもある 图 あまりない

包少しある $\square$ 全くない

(3)話題となっている店や食べ物に関心がありますか

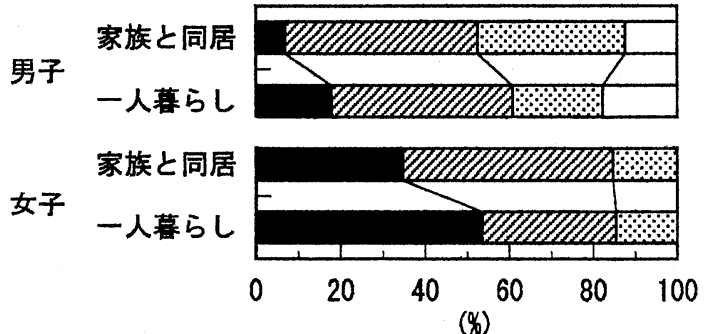

(\%)

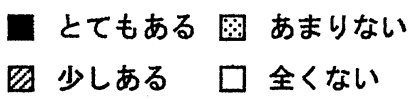

図 3 食生活への関心

た.一人暮らしの学生はしかたなく孤食し，家族と同居 の学生は，家族と食事時間が合わないためか，かなり積 極的に孤食を容認していることが局われる.

質問 3 の「食事の時間」については，女子学生のほぼ 半数が「充分時間をかけたい」と回答し, 逆に男子学生
は「あまり時間をかけたくない」「とくに気にしない」 との回答が $65 〜 78 \%$ を占めるなど，食事時間に対する男 女間の意識差がみられた．殊に一人暮らしの男子学生で あまり時間をかけたくないとの回答が約 $80 \%$ もられ， 生活に対する食事の位置付けが軽んじられる傾向がみら れ，健康な生活を営む上で, 食事の大切さへの認識を高 めるための教育が急務と言えよう.

質問 4 の「家族との食事の時間帯がずれること」につ いては，「気にならない」とする回答が男女とも家族と 同居では $50 \%$ 以上を占めているが，一人暮らしでは25〜 45\%とむしろ少ない傾向が認められた.

質問 5 の「食卓が家族の結びつきを強めるか」の質問 についても，「強めている」とする回答が家族と同居の 学生で40〜 $53 \%$ に対し，一人暮らしでは70～72\% と多く なっていた．このことは，一人暮らしをしている地方出 身学生の方が家族そろっての食事が大切と考えており， 帰省した際の家族との団らんの食事が精神的なやすらぎ に通じると考えているのではないだろうか.

質問 6 の「家庭での食事で最も重視するもの」に対し ては，住まい方を問わず男女学生ともに，「栄養のバラ ンス」を挙げていた．次いで家族と同居の男女学生では 「味」を挙げ，一人暮らしでは男女学生ともに「食費」 を挙げる割合が多く，生活費に占める食費の割合が大き いことの影響といえよう．住まい方を問わず，男女学生 で差が見られた項目は「ボリューム」であり，これはよ く食べる料理の平均エネルギーからも伺える，栄養のバ ランスを重視する意識に対して，実際の食事の実態（前 報1)）からは栄養バランスが良いとは必ずしも言えない ことから, 意識と実態にずれがあることは明らかである.

以上の結果から，大学生の食事に対する満足度は低い 傾向が見られ，しかも孤食を肯定し，また食事の果たす 役割である栄養の充足の面からも，さらには精神的な満 足度からも，十分に食事の役割を果たしていないことが 伺われる．現代の食生活においては，中食・外食が増加 傾向にあり，手作りで手間层をかけるより，手軽に食事 を摂る（調達する）ことができることが現状であり，こ れらのことは食事の画一化を招き，ひいては満足度を低 いものにしているといえよう.

このような食生活からは，栄養面の充足のみならず， 精神的充足，さらには人間関係構築の場としての食の役 割を果たすことができにくくなっていると言えよう。そ のような意味からも, 現代の若者（大学生）の食生活お よびその意識を新たに見直す必要があると思われる. 
(1) 現在の食事をどう思いますか

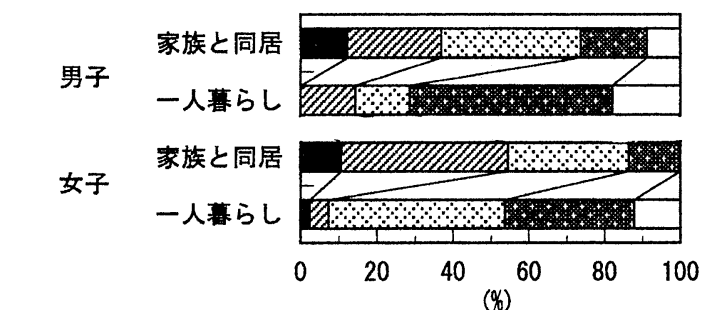

とても満足している 回普通 ロ 不満

ஐやや満足圂 あまり満足でない

(2) 一人で食事をしてもおいしいと思いますか

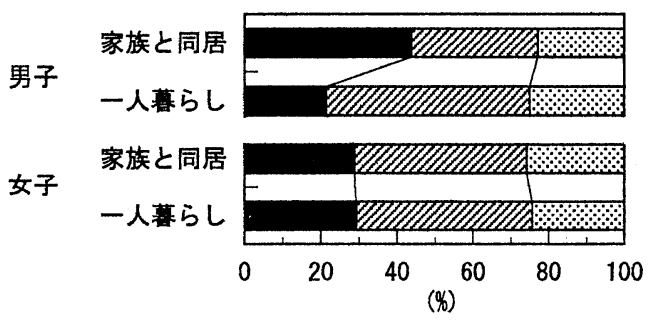

はい ஐどちらともいえない 因 いいえ

(3) 食事に時間をかけたいと思いますか

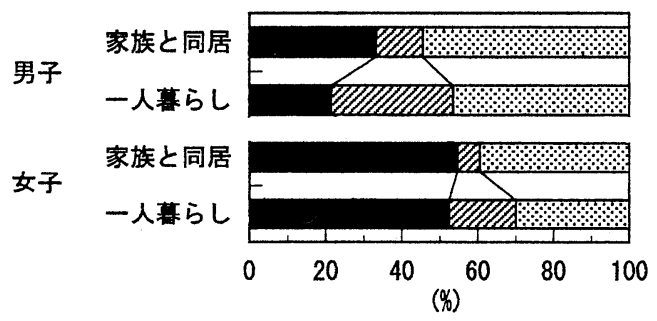

充分に時間をかけたい

凤あまり時間をかけたくない
(4)家族と食事の時間帯がずれることが気になりますか

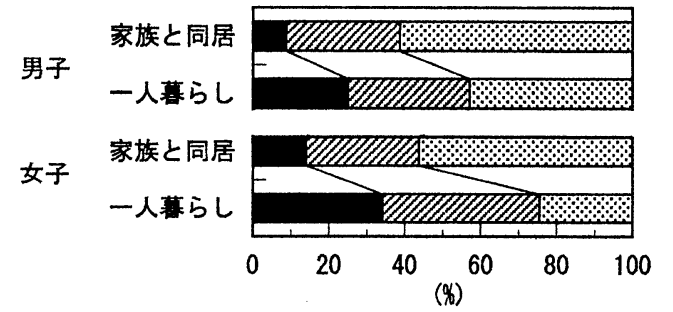

はい 『どちらともいえない 图 いいえ

(5)食卓が家族の結びつきを強めていると思いますか

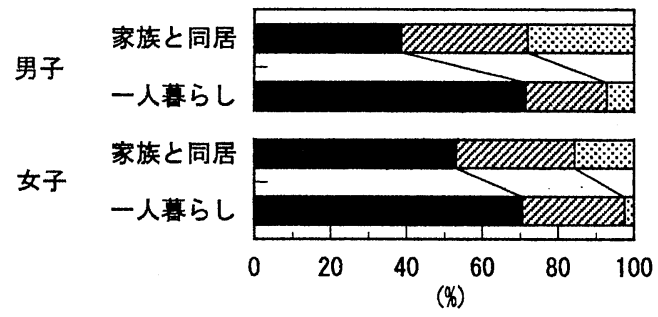

はい囚どちらともいえない 因 いいえ

(6)家庭での食事で最も重視しているのはどれですか

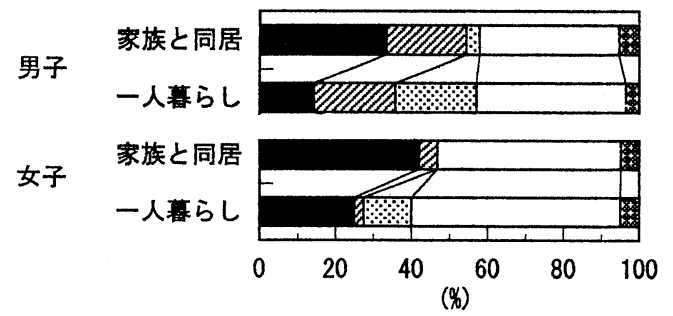

味图食费橉 その他

凤ボリューム $\square$ 栄䕊のバランス

図 4 食事への関心

今回の調査は大学生の食生活への意識の一端をみたも のといえようが，私達が従来から行ってきた基本とする 食事形態よりかけ離れたものであることが前報の実態調 査1) と今回の意識調査の結果より認められた. 現代の大 学生のライフスタイルの中で, 健康で豊かな食生活の向 上をめざすには, 何よりもまず「食べること」の意識を 改めて問い直すための総合的な食教育が必要と考える.

平成13年度から，小学校に食教育の科目の導入が始ま ることを考えると, 次世代の教育を担う大学生の食教育 も急務である. 最も手近な食教育の場として大学生協な どは積極的に大学食堂を活用し, 栄養指導などを実践し
ているが，個々の大学生に対応した給食管理の必要性も 今後の課題ではないであろうか. 現代に適応した食教育 の有効な方法を検討していくことが今後の課題と言えよ う.

\section{要 約}

昨今の大学生の食生活の現状を把握する目的で都内の 大学に在学する男女学生を対象に実態調査（前報）につ づき食嗜好や食事構成因子，食事観などに関する意識調 査を行い, 以下のような結果を得た.

1. 男子学生は肉を主とした洋 - 中国風料理を好むの 
に対し, 女子学生は洋風のスナック料理を好むなど食嗜 好に男女差がみられた。

また高頻度で食べられている料理の種類は限られてお りラーメン, スパゲティ, カレーライスなど定番の一品 ものや菓子, スナックパンなどであった.

2. 日常の食事に対する10項目の質問の因子分析の結 果, 主な因子をみると男女共通の意識では「不規則であ る」が「食べたいものを食べている」と嗜好中心の因子 があがっており，先に報告した実態調査に裏付けられる ものとなった．また，女子では「バランスがとれていな い」「品数が少ない」など自分の食事に対する反省の因 子もあがった．外食についての15項目については男女共 「味」には満足していないものの家族や友人たちとの 「会食」や「手軽さ」をメリットとする因子があがった。

3 . 彼らの食事観を質問した結果, 食生活への関心に ついては男女共現在の食事に「満足」しているものは50 \%に満たなかった.「食事に時間をかけたい（特に女子）」 と思い「食卓が家族の結びつきを強める」ことを肯定す る一方，「家族と時間帯がずれる」ことを気にせず「孤
食」を肯定するなどの素質が大学生達の現実の生活にお いて交錯し，前述の内容を包合する現状の食事には満足 が得られていないことが意識調査からも明らかになっ た。

\section{引用文献}

1）渡辺敦子，飯田文子，川野亜紀，大越ひろ, 三輪里子 : 日 本食生活学会誌，10，45～52（2000）

2）村田輝子, 彦坂令子, 安藤真紀子, 五十川弘子, 鎌田久子, 森岡加代, 山下裕子, 八倉巻和子, 前川當子 : 大妻女子大学 家政学部紀要, 24. 1 13（1998）

3）相川り总子，彦坂令子，小久保清子，秋元ユ力，八倉巻和 子 : 大妻女子大学家政学部紀要, 34, 13 23（1998）

4）田辺由紀, 田中美紀, 金子佳代子：日本食生活学会誌，9， 25 38 (1998)

5）染谷理恵, 根岸由美子, 水野清子, 武藤静子 : 栄養学雑誌, 47, 251 258 (1989)

6）染谷理恵, 根岸由美子, 水野清子, 武藤静子 : 栄養学雑誌, 47, 283 291 (1989)

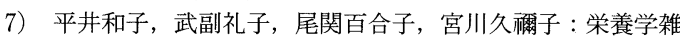
誌， 51，81 89 (1993) 